Доктори техн. наук М.І. Данько, Д.В. Ломотько, I.Е. Мартинов

Doctors of techn. sciences N.I. Dan'ko, D.V. Lomotko, I.E. Martinov

\title{
КАФЕДРА "ВАГОНИ": МИНУЛЕ, СУЧАСНІСТЬ І МАЙБУТНЄ
}

\section{DEPARTMENT OF "WAGON": PAST, PRESENT AND FUTURE}

Історія розвитку залізничного транспорту невід'ємна від історії розвитку рухомого складу залізниць. Післявоєнна відбудова народного господарства СРСР сприяла значному зростанню вантажообігу i потребувала для його забезпечення значної кількості вагонів. Це, в свою чергу, викликало збільшення фахівців, які б забезпечували виготовлення, експлуатацію та ремонт рухомого складу.

$\begin{array}{cc}\text { Кафедра "Вагони" } & \text { Української } \\ \text { державної } & \text { академії }\end{array}$
транспорту була заснована в 1953 році. Їі першим завідувачем став доцент Павло Васильович Шевченко.

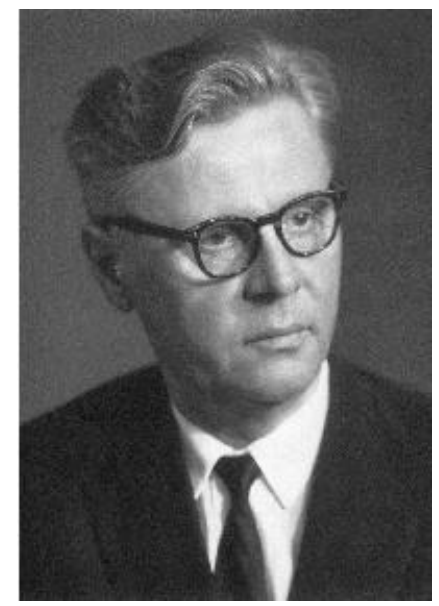

Шевченко Павло Васильович

Павло Васильович Шевченко народився 12 жовтня 1907 р. До вступу в Ленінградський інститут інженерів залізничного транспорту він встиг збути робочу професію та отримати навички практичної роботи. У 1934 р. Павло Васильович закінчив Ленінградський інститут інженерів залізничного транспорту (ЛІІЗТ) і був направлений працювати на Київський паровозовагоноремонтний завод. Там він поступово зростав як фахівець, з 1934 р. по 1937 р. займаючи поступово посади майстра, начальника вагоноскладального цеху i начальника технічного відділу заводу.

Маючи досвід практичної роботи на виробництві, П.В. Шевченко у 1937 р. вступив до аспірантури ЛІІТу по кафедрі "Вагоноремонтні заводи", яку закінчив у 1940 р. Тоді ж він захистив дисертацію на здобуття наукового ступеня кандидата технічних наук i залишився працювати асистентом кафедри.

На початку Великої Вітчизняної війни Павло Васильович був відряджений на Ташкентську залізницю, де до 1944 p. працював заступником начальника служби вагонного господарства.

31943 р. він працював за сумісництвом в. о. доцента кафедри "Рухомий склад та тяга поїздів" Харківського інституту інженерів залізничного транспорту (XIIT), який був евакуйований до Ташкенту. Після повернення 3 евакуації життєвий шлях Павла Васильовича Шевченка нерозривно пов'язаний з нашою академією. 31944 по 
1953 р. Павло Васильович працював доцентом кафедри рухомого складу та тяги поїздів XIIT. У 1944 р. рішенням Вищої Атестаційної Комісії СРСР затверджений у вченому званні доцента кафедри "Рухомий склад та тяга поїздів". Виконував обов'язки начальника навчального відділу інституту. З 1948 по 1950 р. Павло Васильович навчався в докторантурі секції з наукової розробки проблем транспорту Академії Наук СРСР.

У 1953 p. у XIIT була створена кафедра "Вагони та вагонне господарство" і він був затверджений завідувачем кафедри, якою керував беззмінно протягом 29 років, віддаючи усі свої сили і талант розвитку галузевої науки i вихованню кваліфікованих фахівців у вагонобудуванні та вагонному господарстві. За його безпосередньої участі кафедрою підготовлено близько трьох тисяч спеціалістів, які працювали і працюють на різних посадах як в Україні, так і в державах СНД.

У червні 1964 p. доцентом П.В. Шевченком була захищена перша в історії інституту докторська дисертація. У 1965 р. Павлу Васильовичу рішенням ВАК був присуджений вчений ступінь доктора технічних наук і він був затверджений у вченому званні професора кафедри.

За роки наукової діяльності Павло Васильович Шевченко видав більше 50 наукових праць. Його багатогранна діяльність відзначена урядовими нагородами: у 1954 р. він був нагороджений знаком "Почесний залізничник". 31946 по 1975 р. був нагороджений чотирма медалями, а у 1981 p. - орденом "Знак пошани".

У перші роки заснування кафедри разом 3 Павлом Васильовичем працювали доценти М.Ф. Фельдман, I.В. Антонов, B.I. Бабенко, старший викладач К.Г. Рильков, B.I. Максаков. Протягом усього часу існування кафедри “ї колектив активно працював у різних напрямках науково-дослідної роботи, яка була направлена на удосконалення конструкції вузлів вагонів і забезпечення надійності їх роботи в умовах експлуатації. Значні дослідження були виконані П.В. Шевченком 3 питань підвищення надійності пресового з'єднання осі колісної пари вагонів 3 маточиною колеса. На рівні докторської дисертації була виконана робота "Розробка конструкції та розрахунок міцності порожнистих вагонних осей".

Значний внесок щодо удосконалення шарнірних вузлів гальмівної системи i повітропровідної гальмівної магістралі зробив у 1960-ті pp. доцент М.Ф. Фельдман. Під його керівництвом I.В. Антоновим та К.І. Бойко виконувались дослідження відносно можливості застосування на рухомому складі гідравлічних протиюзових авторегуляторів.

3 початку шістдесятих років в інституті значно виросла потреба в науково-педагогічних кадрах i в 1964 р. першими аспірантами кафедри стали В.В. Шевченко і М.В. Коренівський. У подальшому аспірантами П.В. Шевченка стали А.П. Горбенко (нині доцент кафедри), Є.В. Федорець та багато інших.

На кафедрі з'являються досвідчені виробничники, а в минулому її випускники: В.С. Фоменко, О.Г. Мілашич, В.В. Поляков, Д.А. Дубяга, С.І. Нечволода, М.К. Гребьонкін.

До наукової роботи кафедри широко залучались студенти, що мали нахил до наукових досліджень, які потім поповнювали ряди наукових кадрів дослідної лабораторії.

У 1964 р. на кафедрі була створена унікальна науково-дослідна лабораторія "Фотопружність", де активно працював також доцент кафедри "Теоретична механіка" Й.Б. Волькович. Завдяки методу фотопружності з'явилась можливість досліджувати міцність різних вузлів вагонів та інших конструкцій складної геометричної конфігурації та визначати напрямки іiї підвищення. Кафедра активно співпрацювала 3 Маріупольським заводом важкого машинобудування, Уральським, 
Крюківським, Калінінградським і Калінінським (нині Тверським) вагонобудівними заводами. Фахівцями кафедри проводились дослідження поляризаційно-оптичним методом міцності вузла циліндро-поршньової групи двигунів СМД для заводу "Серп і молот", а також перевірялась міцність кріплення лопаток газових турбін для Харківського турбінного заводу.

Наслідком активної наукової діяльності на кафедрі тих років стали захисти дисертацій: докторської - Г.П. Андрєєва (1966 р.) тодішнього ректора Українського заочного політехнічного інституту; кандидатських - В.В. Шевченка (1968р.), А.П. Горбенка, А.О. Радзіховського, М.В. Коренівського (1971 р.), В.Г. Черниша (1975 р.), С.В. Федорця, В.В. Новикова (1977 р.), В.С. Ждамарова (1978 р.). Пізніше, вже після того як пішов із життя д.т.н., професор П.В. Шевченко, продовжуючі його науковий напрямок, стали кандидатами технічних наук C.I. Нечволода (1984 p.), І.Д. Борзилов (1990 р.), М.К. Гребьонкін (1994 р.).

3 середини 1970-х рр. посилилась взаємодія інституту i виробництва. Кафедрою були створені філії у вагонних депо Основа i Харків-пасажирський, які працюють i нині. Тематика курсового i дипломного проектування тісно пов'язана 3 потребами виробництва. Щорічно за замовленням служби вагонного господарства виконувались дипломні проекти, присвячені розробленню окремих питань організації i технології ремонту вагонів. Захист дипломних проектів протягом багатьох років проводився на Харківському вагоноремонтному заводі.

Після того як пішов із життя професор П.В. Шевченко, з 1983 по 1993 р. кафедру очолював доцент Валерій Васильович Шевченко.

Він народився у Харкові 24 січня 1939 р. У 1961 р. закінчив Харківський інститут інженерів залізничного транспорту за спеціальністю "Вагонобудування та вагонне господарство". Після закінчення інституту працював бригадиром, старшим інженером, головним інженером вагонного депо. У 1964 р. поступив до аспірантури на кафедру "Вагони та вагонне господарство" XIITy. У 1967 р. захистив кандидатську дисертацію. 31968 р. - доцент кафедри "Вагони та вагонне господарство".

Валерій Васильович Шевченко очолював кафедру у 1980-ті роки, роки так званої "перебудови". Час потребував змін у всіх галузях, у тому числі і в підготовці фахівців для вагонного господарства. В.В. Шевченко був одним із авторів нових удосконалених навчальних планів для спеціальності "Вагони". Так, замість дисципліни "Взаємодія колії та рухомого складу" була введена дисципліна "Динаміка вагонів". У навчальні плани за рішенням Ради вузу були введені дисципліни "Основи надійності вагонів" і "Основи наукових досліджень". Реалізація принципу безперервної підготовки студентів зі спеціальності призвела до появи дисципліни "Загальна будова вагонів та їх взаємодія 3 технічними засобами залізниць". У 1985 p. було введено дисципліну "САПР і основи наукових досліджень вагонів".

Матеріальна база кафедри неухильно розвивалася. Обмежені можливості розширення площ змушували шукати нові рішення. У 1978 р. кафедрі була передана для навчальних цілей 5-вагонна рефрижераторна секція. Вона розташовувалася на станції Основа. Однак організаційні труднощі, пов'язані 3 ii використанням, змусили відмовитися від цього плану.

У 1983 р. з'явилася ідея створення й установлення на території інституту навчального вагона-лабораторії. Дуже допоміг у реалізації цієї ідеї Ігор Іванович Хаба, який на початку 1980-х рр. очолював службу вагонного господарства Південної залізниці. Служба вагонного господарства передала інституту пасажирський вагон, допомогла відремонтувати і переобладнати 
його на Харківському вагоноремонтному заводі. Технічно складна операція транспортування по місту такого великогабаритного i великовагового об'єкта, як пасажирський вагон, була проведена колективом кафедри в 1984 р.

Кафедра "Вагони" одна 3 перших в інституті почала активно впроваджувати в навчальний процес обчислювальну техніку. На кафедрі змінилося кілька поколінь EOM: Haipi-2, Іскра-226, Іскра-1030M, a також широкий набір засобів аналогової техніки.

Заняття 3 дисциплін "Технологія вагонобудування та ремонту вагонів", "Вагонне господарство", "Автоматизація та механізація ремонту вагонів" проводились у філії кафедри, де студенти мали можливість в умовах депо ознайомитись 3 технологічним процесом ремонту вагонів. Значну частину навчальних занять проводили досвідчені виробничники Г.І. Дуканич, М.К. Костенко.

Наукові дослідження кафедри проводилися головним чином у вигляді госпдоговірних i держбюджетних робіт. Стабільними замовниками були Крюківський, Уральський і Стаханівський вагонобудівні заводи, Головне управління вагонного господарства Міністерства шляхів сполучення СРСР. Для виконання госпдоговірних робіт був створений штат наукових співробітників. Науковими співробітниками працювали С.В. Федорець, Е.В. Лукіна, І.Д. Борзилов, Л.М. Кулик, В.В. Маловічко,

А.В. Гайдамака, Н.Л. Рубанова та ін. За результатами виконаних науково-дослідних робіт багато наукових співробітників захистили дисертації та поповнили ряди викладачів (Е.В. Лукіна, В.В. Маловічко). Широку участь у виконанні науково-дослідних робіт брали студенти.

У 1980-ті рр. наукові зв'язки кафедри 3 виробництвом підтримувалися через суспільний науково-дослідний інститут (СНДІ), у роботі якого на суспільних началах брали участь викладачі інституту і працівники Південної залізниці.

У 1990-х рр. на кафедру прийшли молоді вчені I.Е. Мартинов та О.П. Носач, які захищали свої кандидатські дисертації за іншими науковими напрямками, але теж були в минулому випускниками кафедри.

З 1993 по 1998 р. кафедру очолював к.т.н., доцент А.П. Горбенко. Він закінчив у 1962 p. Дніпропетровський інститут інженерів залізничного транспорту і був направлений у вагонне депо Волноваха Донецької залізниці. Там з 1962 по 1967 р. працював майстром, старшим приймальником вагонів, старшим інженером, головним інженером депо. 3 1967 по 1970 р. навчався в аспірантурі XIIT. Після закінчення аспірантури та успішного захисту кандидатської дисертації А.П. Горбенко 31971 p. працював в XIITi на посадах асистента, доцента кафедри "Вагони". 31976 по 1998 р. працював деканом факультету підвищення кваліфікації керівних робітників і спеціалістів. У 1995 р. пройшов стажування на Швейцарських федеральних залізницях. Він $\epsilon$ автором 76 наукових праць, у тому числі підручника "Вагони промислового транспорту" та навчального посібника 3 провідної дисципліни "Вагони: конструювання та розрахунки", нагороджений знаком "Почесний залізничник". Автор 76 науковометодичних праць, 4 авторських свідоцтв, підручника "Вагоны промышленного транспорта", двох навчальних посібників.

Треба зазначити, що діяльність як навчального закладу в цілому, так i кафедри "Вагони" у 1990-ті рр. минулого сторіччя здійснювалась у дуже складних умовах: відсутність стабільного фінансування, мізерна заробітна платня викладачів із затримками виплати на декілька місяців, мізерні стипендії студентів, що не забезпечували навіть прожитковий мінімум. Впав престиж вищої освіти, скоротилося державне замовлення, 
випускники не могли знайти собі роботу за спеціальністю.

У ці роки на кафедрі під керівництвом А.П. Горбенка проводилась робота 3 подальшого удосконалення навчального процесу. Для підвищення якості навчання вперше був здійснений перехід на європейські стандарти вищої освіти та були розроблені освітньо-професійні програми за професійним рівнем бакалавра, спеціаліста, магістра, проведена організаційно-методична робота щодо переходу на двоступінчасту систему навчання за рівнями "Бакалавр" i "Спеціаліст".

Вперше були розроблені інтегровані навчальні плани безперервної підготовки спеціалістів за системою "технікумакадемія". У результаті розпочато навчання студентів, які мають базову освіту на рівні технікуму, зі скороченим терміном навчання. У навчально-методичний комплекс "академія-технікум" увійшли Одеський, Кременчуцький, Слов'янський, Львівський i Київський технікуми залізничного транспорту.

Для підвищення практичної підготовки студентів суттєво активізована навчальна робота на філії кафедри у вагонному депо Основа.

У період становлення економіки України на ринкових відносинах кафедрою була докорінно змінена концепція виконання дипломних проектів. Головним напрямком тематики їх стала реструктуризація вагонного господарства залізниць України.

Незважаючи на відсутність бюджетного фінансування, подальшого прискорення набула комп'ютеризація навчального процесу. На кафедрі з'явились перші персональні комп'ютери та розроблено прикладні комп'ютерні програми.

Введена в дію гальмова випробувальна станція імітації дії гальм 30 вагонів поїзда при проведенні лабораторних i практичних занять. Матеріально-технічна база кафедри поповнилась приміщенням для створення нової лабораторії холодильного обладнання вагонів.

В інформаційному забезпеченні навчального процесу головна увага приділялась переведенню начального процесу на українську мову, друкуванню методичних вказівок і конспектів лекцій українською мовою.

У рамках науково-дослідних робіт кафедра продовжувала тісно співпрацювати 3 Державною адміністрацією залізничного транспорту України. Згідно 3 державною програмою була виконана науководослідна робота "Розробка заходів по зменшенню зносу пари "колесо-рейка", за виконання якої доцент I.Е. Мартинов був нагороджений Почесною грамотою Укрзалізниці.

Викладачі кафедри брали активну участь у роботі науково-методичної комісії Міністерства освіти України за напрямком "Залізничний транспорт", постійно діючої комісії Укрзалізниці з проблеми зменшення інтенсивності зносу вагонних коліс, технічного комітету України зі стандартизації на залізничному транспорті, науково-технічної ради вагонного главку Укрзалізниці.

На кафедрі відбувся перший випуск магістрів.

Анатолій Петрович Горбенко продовжує працювати доцентом кафедри "Вагони", передаючи свій величезний досвід молодим викладачам.

З 1999 по 2007 р. кафедру "Вагони" очолював д.т.н., професор Владислав Федорович Головко. Він народився 5 травня 1939 р. У 1967 p. закінчив Харківський інститут інженерів залізничного транспорту, отримав диплом 3 відзнакою. 31967 по 1973 р. працював на Харківському заводі ім. В.О. Малишева інженером-дослідником, конструктором. 3 1973 р. працював в Українській державній академії залізничного транспорту спочатку старшим науковим співробітником, асистентом, доцентом, завідуючим кафедрою. У 1975 р. захистив кандидатську 
дисертацію, у 1999 р. - докторську. Основний науковий напрямок діяльності: прогнозування стану та діагностики рухомого складу залізниць. Нагороджений знаком "Почесний залізничник" та орденом "Знак пошани". Він проводив активну роботу з підготовки кваліфікованих кадрів для академії та залізничного транспорту.

Наприкінці 2007 р. Владислав Федорович Головко раптово пішов з життя.

3 січня 2008 р. по вересень 2009 р. обов'язки завідувача кафедри виконував Візняк Руслан Іванович, кандидат технічних наук (2003 р.), доцент (2005 р.), випускник УкрДАЗТ 1999 р. Автор близько 20 наукових і навчально-методичних праць, має 2 патенти на корисну модель і 3 патенти на винахід.

3 вересня 2009 р. по серпень 2010 р. виконував обов'язки завідувача кафедри "Вагони" к.т.н., професор Іван Дмитрович Борзилов. Він у 1977 р. закінчив XIIT за спеціальністю "Вагонобудування та вагонне господарство". Починав роботу на кафедрі молодшим науковим співробітником, потім старшим науковим співробітником і старшим викладачем. У 1990 р. захистив кандидатську дисертацію. 31992 р. - доцент кафедри "Вагони". 3 2004 p. - професор академії по кафедрі вагонів. Має близько 90 наукових праць i навчально-методичних розробок, які стосуються удосконалення технічного обслуговування та ремонту вагонів.

3 вересня 2010 p. і по цей час завідувачем кафедри $є$ доктор технічних наук, професор Ігор Ернстович Мартинов. Він народився у м. Харків у 1962 р. У 1979 р. поступив на механічний факультет Харківського інституту інженерів залізничного транспорту ім. С.М. Кірова, який закінчив з відзнакою у 1984 році за спеціальністю "Вагонобудування та вагонне господарство". Трудову діяльність розпочав у серпні 1984 р. майстром вагоноскладального цеху на Харківському вагоноремонтному заводі. 31984 по 1986 р. проходив строкову службу в лавах
Радянської Армії. 31988 по 1991 p. навчався в очній аспірантурі Московського інституту залізничного транспорту на кафедрі "Вагони та вагонне господарство". У 1991 р. там же захистив дисертацію на здобуття вченого ступеня кандидата технічних наук.

3 лютого 1991 p. по цей час I.E. Мартинов працює в Українській державній академії залізничного транспорту асистентом, доцентом, професором, завідувачем кафедри. Він $\epsilon$ автором понад 100 наукових i науковометодичних праць, у тому числі 5 навчально-методичних посібників 3 грифом Міністерства освіти.

У 2009 р. захистив дисертацію на здобуття вченого ступеня доктора технічних наук на тему "Розвиток методів розрахунку та випробувань буксових підшипникових вузлів вантажних вагонів 3 урахуванням особливостей їх експлуатації". У 2011 р. отримав вчене звання професора.

Під його керівництвом захищено дві кандидатські дисертації.

Основний науковий напрямок діяльності професора I.Е. Мартинова підвищення надійності буксових вузлів рухомого складу. Під керівництвом I.Е. Мартинова виконано комплекс досліджень, присвячений вибору оптимальної конструкції буксового підшипникового вузла вантажних вагонів. Створені буксові вузли підвищеної надійності, обладнані дворядними підшипниками касетного типу, з успіхом експлуатуються на вагонах нового покоління на залізницях України.

За вагомий особистий внесок $\mathrm{y}$ реалізацію Програми щодо зменшення наднормативного зносу коліс i рейок I.E. Мартинов у 2006 p. нагороджений Почесною грамотою Державної адміністрації залізничного транспорту України. За плідну працю і значний внесок у роботу 3 підготовки фахівців залізничного транспорту та підвищення їх кваліфікації I.Е. Мартинов у 2010 р. 
нагороджений Почесною грамотою Міністерства транспорту і зв'язку України. У 2011 р. відзначений іменним годинником від Південно-Західної залізниці.

Кафедрою "Вагони" підготовлено понад три тисячі спеціалістів, які працюють на різних посадах як в Україні, так і в державах СНД. Ведеться підготовка кадрів вищої кваліфікації, діє денна та заочна аспірантура.

Щорічно найкращі студенти кафедри 3 успіхом виступають на всеукраїнських олімпіадах 3 рухомого складу. Так, у

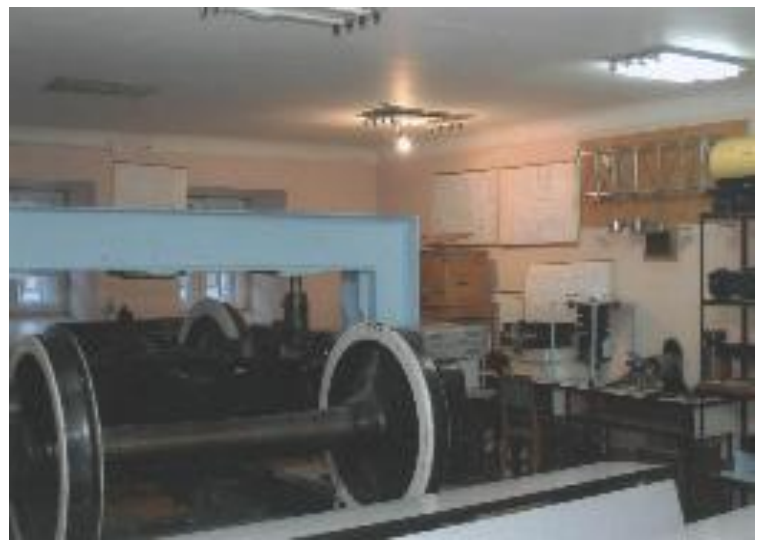

2011 р. перше місце зайняв студент 4-го курсу спеціальності "Вагони та вагонне господарство" Артем Глущенко. На конкурсі студентських наукових робіт дипломом другого ступеня був нагороджений Віталій Юдін.

Лабораторна база представлена шістьма лабораторіями, які оснащені сучасними стендами, приладами та вимірювальною технікою. Лабораторні роботи та практичні заняття проводяться також у вагоні-лабораторії, яка розміщена на території академії.

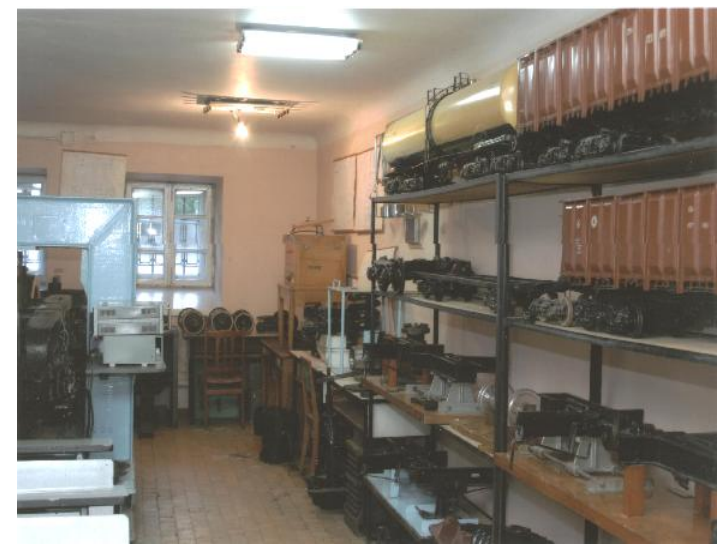

Лабораторія кафедри вагонів

Подальшого прискорення набула комп'ютеризація навчального процесу. Лабораторії кафедри оснащені сучасними комп'ютерами, кількість яких неухильно зростає.

Після закінчення академії інженери цієї спеціальності працюють на підприємствах вагонного господарства залізниць, вагоноремонтних i вагонобудівних заводах, у проектах i науково-дослідних організаціях.

Випускники кафедри вагонів 3 успіхом працюють на всіх залізницях України та інших країн СНД. М.І. Скорина очолював Головне управління вагонного господарства Міністерства шляхів сполучення СРСР, Л.М. Лобойко успішно працював начальником вагонної та пасажирської служби Південної залізниці, заступником Генерального директора
Укрзалізниці, першим керівником Української залізничної швидкісної компанії. На сьогодні начальником Головного управління вагонного господарства працює О.В. Кутішенко, головним інженером цього ж управління В.В. Мархай. В.В. Регеда багато років очолював вагонну службу Донецької залізниці, зараз ii очолюе П.А. Куліков, В.Б. Мельничук очолює вагонну службу Львівської залізниці, А.О. Мусієнко вагонну службу Південної залізниці, С.В.Бут - ऑї головний інженер. С.В. Васильєв працює головним інженером служби вагонного господарства Одеської залізниці, начальник пасажирської служби Південної залізниці - I.О. Плескач, директор Стрийського ВРЗ А.Д. Алєксєєнко, головний інженер 
Державного підприємства "Укрспецвагон" - В.Р. Новіков, ректор ДЕТУТ М.В. Макаренко, проректор УкрДАЗТ А.О. Каграманян та інші. На всіх посадах випускники кафедри з честю несли почесне звання вагонника. За роки існування кафедри "Вагони" було випущено понад шість тисяч спеціалістів, 3 них 189 з відзнакою.

На кафедрі "Вагони" ведеться підготовка кадрів вищої кваліфікації, діє денна та заочна аспірантура.

Через систему Науково-навчального Інституту підвищення кваліфікації та перепідготовки кадрів кафедра веде підготовку магістрів денної та заочної форми навчання та навчальний процес 3 отримання другої спеціальності за спеціальністю "Вагони та вагонне господарство".

Останнім часом на кафедрі під керівництвом професора I.Е. Мартинова виконуються наукові дослідження 3 підвищення надійності буксових вузлів вагонів шляхом удосконалення конструкції та впровадження сучасних технологій діагностування технічного стану його елементів (к.т.н., доцент А.В. Труфанова, В.М. Петухов, В.Г. Равлюк, В.О. Юдін, В.О. Шовкун). У рамках реалізації цього напрямку було розроблено та впроваджено 4 нормативних документи, які забезпечують експлуатацію та ремонт буксових вузлів підвищеної надійності (Інструкція 3 технічного обслуговування букс, обладнаних касетними конічними підшипниками ЦВ-ЦЛ-0092, Інструкція 3 технічного обслуговування та монтажудемонтажу букс, обладнаних здвоєними циліндричними підшипниками касетного типу CRU-Дуплекс ЦВ-0125, Технологічна інструкція 3 проведення монтажнодемонтажних робіт букс, обладнаних дворядними підшипниками касетного типу, Інструктивні вказівки "Підшипники вагонні дворядні касетного типу. Норми безпеки").

Над удосконаленням системи технічного утримання вагонів для підвищення ефективності їх використання працює професор І.Д. Борзилов. Питанням модернізації гальмівної системи вантажних вагонів присвячені дослідження доцента C.I. Нечволоди, розробленню заходів щодо зменшення інтенсивності спрацювання деталей ходових частин вагонів - доцента А.П. Горбенка. Над створенням сучасних засобів технічного діагностування колісних пар пасажирських вагонів під керівництвом доцента В.В. Бондаренко працює Д.І. Скуріхін. Дослідження доцента P.I. Візняка та А.О. Ловської присвячені забезпеченню збереження вагонів у міжнародному залізнично-водному сполученні.

За зазначеними напрямками наукової діяльності кафедра тісно співпрацює 3 Головним управлінням вагонного господарства, Головним пасажирським управлінням, Головним управлінням приміських пасажирських перевезень Укрзалізниці, Державним підприємством "Український науково-дослідний інститут вагонобудування", службами вагонного господарства та пасажирськими службами залізниць України, проектноконструкторським бюро Головного управління вагонного господарства Укрзалізниці, Державним підприємством Укррефтранс, ПАТ "Крюківський вагонобудівний завод", ВАТ "Харківський підшипниковий завод", а також з багатьма іншими підприємствами та установами.

Кафедра співпрацює зі спорідненими кафедрами Московського та СанктПетербурзького університетів шляхів сполучення (Росія), а також з провідними світовим виробниками підшипникових вузлів для рухомого складу: шведською фірмою "SKF", американськими компаніями "Timken" та "Brenco", Свропейською підшипниковою корпорацією.

У 2011 р. на кафедрі в рамках 73-ї міжнародної науково-практичної конференції кафедр академії, інженернотехнічних працівників залізниць, підприємств та організацій України в 
роботі секції "Вагони" взяло участь 48 осіб. Серед них представники Державного підприємства "Державний науководослідний центр" Укрзалізниці (м. Київ), Державного економіко-технологічного університету транспорту (м. Київ), Національного технічного університету "Харківський політехнічний інститут", Державного науково-дослідного інституту вагонобудування, ПАТ Крюківський вагонобудівний завод (м. Кременчук), концерна "Азовмаш" (м. Маріуполь), фахівці Південної та Львівської залізниць. 3 доповідями виступили науковці Московського державного університету шляхів сполучення (Росія), а також представники виробників підшипникових вузлів для рухомого складу "Schaeffler technologies gmbh \& CO KG" (Німеччина) та SKF Eurotrade AB (Швеція).

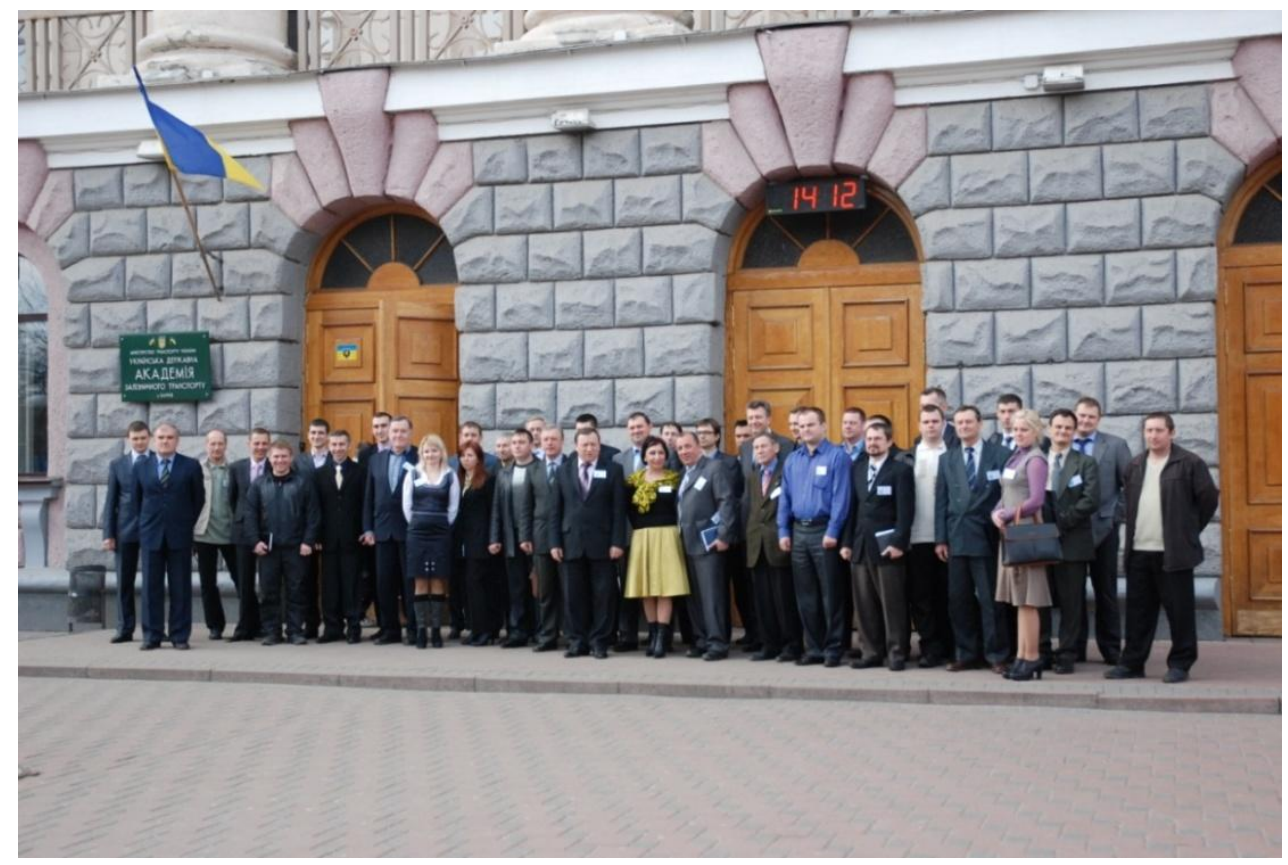

Учасники 73 міжнародної науково-практичної конференції кафедр академії, секція "Вагони" (квітень 2011 р.)

Ключові слова: історія, підготовка спеціалістів, освіта.

\section{Анотаціï}

Стаття присвячена історії кафедри вагонів, основним напрямкам ii розвитку та становлення. Розкриваються сфери наукової діяльності співробітників кафедри, участь кафедри у житті факультету та розвитку науки України і Укрзалізниці.

Статья посвящена истории кафедры вагонов, основным направлениям ее развития и становления. Раскрываются сферы научной деятельности сотрудников кафедры, участие кафедры в жизни факультета и развития науки Украины и Укрзализныци.

The article is devoted to the history of the Department wagons, main directions of its development and formation. Disclosed sphere of scientific activities of the Department, part of the Department in the faculty life and development of science of Ukraine and Ukrzaliznytsia. 